\title{
Conflicts and compromise
}

Citation for published version (APA):

Li, S. (2019). Conflicts and compromise: Internationalization of competition law. [Doctoral Thesis, Maastricht University]. ProefschriftMaken Maastricht. https://doi.org/10.26481/dis.20191206sl

Document status and date:

Published: 01/01/2019

DOI:

10.26481/dis.20191206sl

Document Version:

Publisher's PDF, also known as Version of record

\section{Please check the document version of this publication:}

- A submitted manuscript is the version of the article upon submission and before peer-review. There can be important differences between the submitted version and the official published version of record.

People interested in the research are advised to contact the author for the final version of the publication, or visit the DOI to the publisher's website.

- The final author version and the galley proof are versions of the publication after peer review.

- The final published version features the final layout of the paper including the volume, issue and page numbers.

Link to publication

\footnotetext{
General rights rights.

- You may freely distribute the URL identifying the publication in the public portal. please follow below link for the End User Agreement:

www.umlib.nl/taverne-license

Take down policy

If you believe that this document breaches copyright please contact us at:

repository@maastrichtuniversity.nl

providing details and we will investigate your claim.
}

Copyright and moral rights for the publications made accessible in the public portal are retained by the authors and/or other copyright owners and it is a condition of accessing publications that users recognise and abide by the legal requirements associated with these

- Users may download and print one copy of any publication from the public portal for the purpose of private study or research.

- You may not further distribute the material or use it for any profit-making activity or commercial gain

If the publication is distributed under the terms of Article $25 \mathrm{fa}$ of the Dutch Copyright Act, indicated by the "Taverne" license above, 


\section{Summary}

The last several decades have been characterized by a global expansion of competition law. Contrasting decisions against the same anti-competitive conduct by agencies from different countries have led to some serious conflicts between jurisdictions. This thesis explains the origin of these conflicts and examines the possibilities to reduce these conflicts in the future.

The first part of the thesis concentrates on conflicts. It includes an introduction and a discussion of the reasons for conflicts. Competition law has been adopted by many jurisdictions to regulate the conduct of market participants. Its rapid expansion and development all over the world have been noticeable especially since the 1990s. Along with the globalization, increasing numbers of multi-national companies and cross-border transactions have greatly encouraged the interaction between different markets in the world (Chapter 1). Against this background, in order to effectively protect the competition in their markets, more and more jurisdictions have accepted that the application of domestic competition law should not be restricted to its territory (Chapter 2). Significant differences between competition regimes (both as far as the underlying goals and the contents of the rules are concerned) and extraterritorial application of competition law are key factors leading to conflicts between jurisdictions.

The second part mainly focuses on cooperation between jurisdictions, including an examination of attempts made by the international community to avoid or decrease possible conflicts at the bilateral (Chapter 3), regional (Chapter 4) and international (Chapter 5) level. Competition regimes have different views about how to solve these conflicts and which level of regulation is most suitable to reach a solution. In general, cooperation at each level has both advantages and disadvantages. Bilateral cooperative instruments are widely used, flexible and relatively easy to reach. However, in many circumstances, for example, if more than two jurisdictions are involved, the effectiveness of bilateral cooperation is doubtful. Regional cooperation extends the geographic scope of bilateral cooperation and can identify specific regional situations. However, the often general and vague provisions, the overlapping regional blocs and the difficulties to effectively ensure regional cooperation hardly make it an optimal solution. Attempts to reduce conflicts at the international level have also included several proposals to form international competition rules or mechanisms, especially through international organizations, such as the WTO, the OECD and the ICN. The attempts to formulate hard law rules in the realm of competition law have failed, but the efforts to establish some soft law rules have achieved some success. However, currently, none of the cooperation at these levels could really solve the problem of conflicts.

The third part conducts a theoretical analysis of the solutions and attempts made so far. It starts with discussing the important question of whether centralization at the 
international level is feasible in the area of competition law (Chapter 6). Although centralization at the international level provides a possible theoretical solution for reducing the conflicts between jurisdictions in the area of competition law, it can hardly be regarded as the optimal solution as explained in this thesis. By contrast, the international community seeks international law and international institutions to reduce the conflicts or their harm. This thesis applied game theory in order to examine these solutions. Based on the analysis, it is concluded that bilateral agreements, soft law rules and international networks can play more important roles in controlling the conflicts. (Chapter 7)

The conclusion and final remarks provide a summary, an observation and a number of policy recommendations in the end. 